LAWRENCE LIVERMORE N A T IO N A L LABORATORY
Perchlorate and Nitrate Remediation Efficiency and Microbial Diversity in a Containerized Wetland Bioreactor

Bill Daily Jr., Valerie Dibley, Holly Pinkart, Tina Legler

June 16, 2004

International Journal of Phytoremediation 


\title{
Perchlorate and Nitrate Remediation Efficiency and Microbial Diversity in a Containerized Wetland Bioreactor
}

\author{
Paula Krauter, ${ }^{1}$ Bill Daily Jr., ${ }^{1}$ Valerie Dibley, ${ }^{1}$ Holly Pinkart, ${ }^{2}$ and Tina Legler ${ }^{1}$ \\ ${ }^{1}$ Lawrence Livermore National Laboratory, 7000 East Ave., Livermore, CA 94550 \\ ${ }^{2}$ Central Washington University, Ellensburg, WA 98926
}

Corresponding author:

Paula Krauter

e-mail: krauter2@1lnl.gov

phone: (925) 422-0429

fax: (925) 422-2095

Running head: Wetland Bioreactor for Remediating Groundwater 


\section{DISCLAIMER}

This document was prepared as an account of work sponsored by an agency of the United States Government. Neither the United States Government nor the University of California nor any of their employees, makes any warranty, express or implied, or assumes any legal liability or responsibility for the accuracy, completeness, or usefulness of any information, apparatus, product, or process disclosed, or represents that its use would not infringe privately owned rights. Reference herein to any specific commercial product, process, or service by trade name, trademark, manufacturer, or otherwise, does not necessarily constitute or imply its endorsement, recommendation, or favoring by the United States Government or the University of California. The views and opinions of authors expressed herein do not necessarily state or reflect those of the United States Government or the University of California, and shall not be used for advertising or product endorsement purposes. 


\begin{abstract}
We have developed a method to remove perchlorate (14 to $27 \mu \mathrm{g} / \mathrm{L})$ and nitrate (48 mg/L) from contaminated groundwater using a wetland bioreactor. The bioreactor has operated continuously in a remote field location for more than two years with a stable ecosystem of indigenous organisms. This study assesses the bioreactor for long-term perchlorate and nitrate remediation by evaluating influent and effluent groundwater for reduction-oxidation conditions and nitrate and perchlorate concentrations. Total community DNA was extracted and purified from 10-g sediment samples retrieved from vertical coring of the bioreactor during winter. Analysis by denaturing gradient gel electrophoresis of short, $16 \mathrm{~S}$ rDNA, polymerase-chain-reaction products was used to identify dominant microorganisms. Bacteria genera identified were closely affiliated with bacteria widely distributed in soils, mud layers, and fresh water. Of the 17 dominant bands sequenced, most were gram negative and capable of aerobic or anaerobic respiration with nitrate as the terminal electron acceptor (Pseudomonas, Acinetobacter, Halomonas, and Nitrospira). Several identified genera (Rhizobium, Acinetobactor, and Xanthomonas) are capable of fixing atmospheric nitrogen into a combined form (ammonia) usable by host plants. Isolates were identified from the Proteobacteria class, known for the ability to reduce perchlorate. Initial bacterial assessments of sediments confirm the prevalence of facultative anaerobic bacteria capable of reducing perchlorate and nitrate in situ.
\end{abstract}

Key terms: perchlorate removal, nitrate removal, groundwater remediation. 


\section{Introduction}

For more than 40 years, ammonium perchlorate has been used in military and civilian applications, including use in rocket propellants, automobile air bags, and fireworks. The perchlorate ion $\left(\mathrm{ClO}_{4}^{-}\right)$is a highly reactive and powerful oxidizing agent in high concentrations and temperatures, yet is very stable in surface and subsurface water below $1000 \mu \mathrm{g} / \mathrm{L}$ (AWWARF, 1997). Such physical qualities make perchlorate useful for propellant applications; however, the physical and chemical properties of perchlorate contribute to rapid dissolution and can result in dispersion into surface and subsurface waters, causing contamination. Ammonium perchlorate readily dissolves into the ammonium $\left(\mathrm{NH}_{4}{ }^{+}\right)$cation and perchlorate anion in aqueous solutions. According to the U.S. Environmental Protection Agency (U.S. EPA), perchlorate has been manufactured or used in 44 states, and at least 18 of those states have reported releases (U.S. EPA, 2001; California Department of Public Health, 2001).

The perchlorate anion poses potential health concerns because its ionic radius and charge are similar to that of iodine, which allows perchlorate to competitively block thyroid iodine uptake and inhibit normal thyroid hormone production (Nzengung, Wang, and Harvey, 1999). Smith et al. (2001) found that aquatic organisms inhabiting perchloratecontaminated water bodies contained detectable concentrations of perchlorate and that terrestrial species can be exposed from contaminated soils or vegetation. Water suppliers in California have detected perchlorate in 145 public water supply wells. There is no National Primary Drinking Water Regulation (NPDWR) or Health Advisory established for perchlorate. However, California has established an action level for perchlorate of 
$>18 \mu \mathrm{g} / \mathrm{L}$ (U.S. EPA, 2001). The California Department of Health Services recently revised its action level down to $4 \mu \mathrm{g} / \mathrm{L}$, which corresponds to the detection limit for perchlorate analysis using EPA Method 314.0 for perchlorate. Perchlorate was detected in groundwater, with concentrations ranging from 5 to $65 \mu \mathrm{g} / \mathrm{L}$, in several locations at Lawrence Livermore National Laboratory's (LLNL's) high-explosives test facility (Site 300) in 1999.

The potential role of bioremediation to clean up groundwater contaminated by nitrate and perchlorate salts led to interest in developing and evaluating related technologies, including wetland bioreactors. Common methods of remediating perchlorates from groundwater include adsorption by activated carbon, reverse osmosis, ion exchange, capacitive deionization (CDI), and bioremediation. Adsorption by activated carbon is ineffective because of rapid saturation of adsorption sites and competition with other anions, such as nitrate. Reverse osmosis, capacitive deionization, and ion exchange are relatively expensive and produce hazardous-waste-containing salts and perchlorates. Reverse osmosis has limited capacity and requires effluent reconditioning. CDI uses high-surface-area electrodes to promote double-layer charging that causes ion separation and sorption on electrodes. The CDI method requires regeneration of electrodes and treatment of the related concentrated fluids. Ion-exchange regeneration typically calls for a large quantity of resin that requires complex and expensive regeneration processes. Spent resin is considered secondary hazardous waste. New remediation strategies include bioreactors, natural attenuation, catalytic reactor systems, and enzyme catalytic-reactor systems (Hurley, 2001). 
Biologically mediated reduction of perchlorate has been used successfully in the remediation of perchlorate in a fixed-bed reactor (Wallace et al., 1998), an autotrophic packed-bed bioreactor (Giblin, Herman, and Frankenberger 2000b), and a wetland bioreactor (Krauter, 2001a). Under proper conditions, perchlorate undergoes microbially mediated transformation into chlorate, chlorite, oxygen, and chloride (Malmqvist, Welander, and Gunnarsson, 1991; Rikken, Kroon, and van Ginkel, 1996; Urbansky, 1998; Coates et al, 1999; Herman and Frankenberger, 1999; Urbansky and Schock, 1999; and Giblin et al., 2000a). Logan et al. (2001) isolated ten chlorate-respiring bacteria, some of which were able to degrade perchlorate.

Because of the stability of perchlorates in water and the number and extent of perchlorate-contaminated sites, development of simple and cost effective technologies to degrade perchlorate and nitrate in contaminated groundwater is necessary. At LLNL, perchlorate is co-located with nitrate; therefore, we needed a technique that could remediate both contaminants from groundwater. An additional challenge, namely that there was a 1000-fold difference in nitrate versus perchlorate concentration in groundwater, meant that our remediation technique had to be capable of removing small quantities of perchlorate.

The objectives of this study were (1) to determine if a wetland bioreactor could remove microgram-per-liter concentrations of perchlorate and milligram-per-liter concentrations of nitrate from groundwater in a continuous-flow treatment facility, and (2) to evaluate the chemical properties over an extended time. Important parameters, such as hydraulic residence time, carbon source availability, electron acceptor concentrations, and environmental temperatures, may influence the degradation of perchlorate in the 
bioreactor. Because the wetland bioreactor has operated for more than two years with a stable ecosystem of indigenous microorganisms, we identified the dominant species in the reactor and in reactor effluent water.

\section{Study Area}

LLNL's Site 300 is a Department of Energy (DOE) high-explosive test facility located in the southeastern Altamont Hills of the Diablo Range in Northern California. As shown in Figure 1, it is situated approximately 97 kilometers east of San Francisco, and it covers 27 square kilometers. The climate of Site 300 is semiarid and windy, with typical rainfall of 25 to $28 \mathrm{~cm}$ per year.

Facilities in the Building 854 area of Site 300 were used to test the stability of weapons and weapon components under various environmental conditions and mechanical stresses. Tests conducted during the 1960s may have included ammonium chemicals, primarily the volatile organic compound (VOC) trichloroethylene (TCE), and such chemicals were released to the subsurface as a result of test activities. Other contaminants found in Building 854 groundwater are nitrate and perchlorate (Ferry et al. 2001). The Building 854 Proximal Treatability Test (B854-PRX) has been operating since November 2000.

Figure 2 shows isocontours of groundwater-contaminant plumes of TCE, nitrate, and perchlorate. Perchlorate was detected in groundwater samples from eight wells in the Building 854 area. The maximum perchlorate concentration $(27 \mu \mathrm{g} / \mathrm{L})$ was detected in a sample collected from well W-854-1823 in March, 2003. Nitrate was detected at concentrations exceeding the $45-\mathrm{mg} / \mathrm{L}$ discharge limit in groundwater samples from 
seven wells in the Building 854 area (maximum concentration was $55 \mathrm{mg} / \mathrm{L}$ ). The distribution of nitrate shown in Figure 2(c) does not suggest a specific source area. It is likely that the nitrate is from both natural and anthropogenic sources.

\section{Geology and Hydrogeology}

Building 854 is located on the southern limb of the Patterson Anticline. Much of the area is underlain by a Quaternary landslide (Q1s) deposit that is more than $15 \mathrm{~m}$ thick at some locations. The Qls is characterized by large, angular, weathered-bedrock fragments and may have rotated beds due to slumping along a plane of detachment. Although the Qls appears to be unsaturated throughout most of the area, some water has been encountered in wells south and east of the primary area.

Immediately beneath the landslide deposit, in descending order, are the Tertiary-age Neroly Formation, the Lower Blue Sandstone unit $\left(\mathrm{Tnbs}_{1}\right)$, the Neroly sandstone-siltstone unit $\left(\mathrm{Tnsc}_{0}\right)$ and the underlying Cierbo Formation (Tmss). Fracturing is an important flow-controlling feature in $\operatorname{Tnbs}_{1} / \operatorname{Tnsc}_{0}$ hydrostratigraphic units. Groundwater is also present in the $\mathrm{Tnbs}_{1}, \mathrm{Tnsc}_{0}$, and Tmss units.

$\mathrm{Tnbs}_{1}$, which appears to be the primary contaminant pathway, has a water-bearing zone that extends throughout much of the Building 854 area, from north of monitoring well W854-05 to south of W-854-07 (see Figure 2). Assuming a matrix porosity of 0.3 , the groundwater flow velocity is approximately $45.7 \mathrm{~cm} /$ day.

\section{Methods}

\section{Bioreactor Configuration and Operation}


As shown in Figure 3, groundwater was pumped from a well (W-854-03) using solar energy into granular activated carbon (GAC) canisters to remove VOCs. It has been observed at this and other similar facilities that GAC does not efficiently remove nitrate or perchlorate ions or salts from groundwater. After VOC removal, the water was then distributed to multiple wetland bioreactor tanks. The wetland bioreactors consist of four tanks containing coarse, aquarium-grade gravel. Two tanks were 1.9-kL capacity (1.8-m diameter) and two were 4.2-kL capacity (2.4-m diameter). The containers were planted with cattails (Typha species) and sedges (Cyperus species). The plant species were obtained from local arroyos and chosen for their availability and vigor. No inocula were added to the system. Groundwater was allowed to circulate through the bioreactor for three weeks to acclimate the wetland plants and to build a biofilm from indigenous flora. The recirculation system was then replaced with a constant flow of untreated groundwater.

Tank volume was chosen to accommodate a $3.8-\mathrm{L} / \mathrm{min}$ flow rate with a hydraulic retention time of about 17 to 20 hours. The two 1.9-kL tanks, in parallel, were raised about $61 \mathrm{~cm}$ above ground to allow for gravity flow into the two $4.2-\mathrm{kL}$ tanks in parallel. Water flowed from top to bottom in each tank, then through a conduit into the next tank in series. The split flow of $2 \mathrm{~L} / \mathrm{min}$ from each, parallel, 1.9- and 4.2-kL tank series configurations was combined at the discharge of the bioreactor. Water levels in each tank were maintained by a system of adjustable weirs. Hydraulic retention time (HRT) was the total time for groundwater to flow from the reactor influent hose, through the tanks, into the effluent hose. The HRT was controlled by the influent-flow control valve. As a 
precaution, bioreactor effluent water was filtered through Sybron ${ }^{\mathrm{TM}}$ ASB-7 ion exchange resin to ensure that perchlorate was removed prior to flowing into an infiltration trench.

\section{Analytical Methods}

Perchlorate concentrations in groundwater were determined through a certified analytical laboratory (EPA Method 300.0, detection limit $4 \mu \mathrm{g} / \mathrm{L}$; Weck Laboratory, City of Industry, CA) using ion chromatography. Samples were collected in precleaned, 40-mL vials. All vials were completely filled with groundwater, leaving no headspace. Samples were stored at $4{ }^{\circ} \mathrm{C}$ prior to analysis and were analyzed within 28 days, in accordance with recommendations for storage and handling (California Dept. of Health Services 1997; Dionex Corp. 1998). Blanks, laboratory control samples, and performance evaluation samples were analyzed with each batch of samples. Performance evaluation standards for perchlorate were purchased from Environmental Resource Associates (Arvada, CO).

\section{Geochemical Analyses}

Chemical analyses of groundwater samples were performed in the field and in certified laboratories. Temperature, $\mathrm{pH}$, and redox measurements were performed using a Beckman $210 \mathrm{pH}$ meter and a $\mathrm{pH}$ electrode (\#38941), or a redox potential (ORP) platinum combination electrode (\#511120, Beckman Inst., Fullerton, CA). Field measurements of dissolved oxygen, nitrate, $o$-phosphate, and sulfide were conducted using a VVR photometer and water analysis systems (Chemetrics, Calverton, VA). Each field measurement was taken in triplicate, and the average value was recorded. Field analyses were considered semi-quantitative. Analyses of ammonia, nitrate, nitrite, iron, manganese, sulfate, total alkalinity, hardness, chloride, potassium, calcium, sodium, 
magnesium, total organic carbon, and total dissolved solids in groundwater were performed by certified laboratories (BC Laboratories Inc., Bakersfield, CA; Sequoia Analytical, San Carlos, CA). Samples were collected by qualified personnel using EPA procedures. VOCs were analyzed using EPA Method 601, nitrate by EPA 300.0, perchlorate by EPA 314.0, dissolved organic carbon (DOC) by EPA 415.1, and total dissolved solids (TDS) by EPA 160.1. Appropriate containers and trip blanks were obtained from the analytical laboratories. After collection, bottles were sealed in selfsealing plastic bags and placed in an iced cooler. The analytical laboratories analyzed one method blank, matrix spike, matrix spike duplicate, and one laboratory control sample/standard with every batch of 20 samples.

Treatment system samples were collected at the influent and effluent and analyzed at least monthly for VOCs, nitrate, perchlorate, and TDS. Samples were also collected and analyzed in the field for $\mathrm{pH}$, electrical conductivity, and temperature using portable field instruments. Additional treatment-system optimization samples were collected at least monthly from the VOC treatment unit effluent (shown in Figure 3) and from bioreactor effluent and analyzed for nitrate, perchlorate, and DOC. Field quality-control samples included a field blank and duplicate.

\section{Denaturing Gradient Gel Electrophoresis Procedure}

Denaturing gradient gel electrophoresis (DGGE) was used to identify dominant microorganisms living in the reactor. Sediment samples were retrieved from noncontinuous, vertical coring of the wetland bioreactor. One-gram sediment samples were placed in a bead-beating tube and vortexed. The cells were lysed, and released DNA 
was bound to a silica spin filter, washed, and released into 10-mM Tris (MoBio Lab, Inc.). Water samples were filtered through a cellulose acetate filter membrane. Organisms collected on the filter were lysed, and the DNA was bound to a spin filter, washed, and released into $10 \mathrm{mM}$ Tris. The DNA was extracted with a phenol-chloroform-isopropyl solution.

The $16 \mathrm{~S}$ ribosomal DNA (rDNA) was amplified by the polymerase chain reaction (PCR) using universal primers, 9968 and r1401, according to the methods of Weisburg et al., (1991) including a 40-bp, 5-in. GC clamp. Controls either lacking template or primers were analyzed on a $1 \%$ agarose gel to confirm the absence of detectable PCR artifacts.

DGGE was performed using a Bio-Rad Dcode Universal Mutation Detection System (Bio-Rad Life Sciences Products, Hercules, CA). Aliquots (35 $\mu 1)$ of PCR samples mixed with $4 \mu \mathrm{l}$ of loading dye were loaded onto $8 \%$ (weight/volume) polyacrylamide gels that contained a $35 \%$ to $65 \%$ denaturant gradient (prepared as described in the Bio-Rad DGGE protocol) in $0.5 \mathrm{X}$ TAE buffer. Electrophoresis was performed at a constant voltage of $85 \mathrm{~V}$ and temperature of $60^{\circ} \mathrm{C}$ for 14 hours. Following electrophoresis, the gels were stained in an ethidium bromide solution for 15 minutes and destained for 10 minutes. Gels were visualized with a Bio-Rad Molecular Imager FX, set to a resolution of $50 \mu \mathrm{m}$, to scan the gel images into a Macintosh computer system. The gel images were digitized and viewed with Bio-Rad Quantity One software. Dominant bands were excised and sequenced (Biotech Core, Inc., Mountain View, CA). Additional sequence analysis was performed using ClustalV, GeneDoc, and GenBank BLAST software packages.

\section{Statistical Analysis}


Linear regression analysis was conducted on data to determine whether there was a relation between variables. The linear least-squares regression method was used to determine the best curve fit for the data. The correlation coefficient represented the relation between $x$ and $y$ data points in the fitted data series to indicate how well the curve fit each selected data series.

\section{Results}

Over 24 months, $2815 \mathrm{~kL}$ of groundwater was processed through the wetland bioreactor. The solar-powered facility operated about 10 to $15 \mathrm{hr} /$ day, depending on cloud cover, hours of sunlight, and battery storage capacity. The flow rate was set at $3.8 \mathrm{~L} / \mathrm{min}$, so the minimum reactor hydraulic retention time was about $17 \mathrm{hr}$ during times of active flow. As plants matured, the retention time may have decreased because organic debris and rootlets occupied some of the tank volume.

Table 1 summarizes the results of groundwater analysis from the bioreactor supply well, W-854-03. Influent groundwater concentrations of perchlorate were greater than the California action level of $4 \mu \mathrm{g} / \mathrm{L}$, ranging between 5.8 and $14 \mu \mathrm{g} / \mathrm{L}$ (Figure 4). The influent water contained dissolved oxygen $(8 \mathrm{mg} / \mathrm{L})$ and had a $\mathrm{pH}$ of 7.6 . The reduction-oxidation value as measured by $E_{\mathrm{h}}$ ranged between 118 and $167 \mathrm{mV}$.

Groundwater temperature was generally 18 to $21^{\circ} \mathrm{C}$. Table 2 shows that monthly air and water temperature of the bioreactor water fluctuated with the season from November 2000 to November 2002. Average water temperature within the bioreactor ranged from 7.5 to $25.4^{\circ} \mathrm{C}$. Bioreactor reduction-oxidation potential ranged from approximately -100 to $-150 \mathrm{mV}$ when the bioreactor had established the indigenous microbial community 
and native plants. Effluent water-dissolved oxygen content was generally $<1 \mathrm{mg} / \mathrm{L}$. The influent $\mathrm{pH}$ of about 7.5 decreased to around 7.0 units in effluent water.

The first tanks in series were injected with acetic acid to supply a carbon source to stimulate bacterial cell growth. After initial startup and during the months of April through August, perchlorate was occasionally detected in bioreactor effluent. Such breakthroughs coincided with problems with the acetic acid injection system. No perchlorate was detected in bioreactor effluent in 13 of the 24 months that the system was in operation. Replacing a venturi-type pump with a peristaltic pump alleviated the problem associated with injecting acetic acid.

As shown in Figure 5, the concentration of nitrate in influent water remained relatively stable over the 24 months, ranging from 42 to $48 \mathrm{mg} / \mathrm{L}$. The quadratic curve fit of effluent nitrate concentration data demonstrated the improved nitrate removal capacity in effluent water as the plants and microbial community were established and matured in the tanks. The groundwater treatment generally removed nitrate to concentrations below the detection limit $(<5 \mathrm{mg} / \mathrm{L})$. Occasionally during early spring, nitrate concentrations of treated water increased to $31 \mathrm{mg} / \mathrm{L}$.

Active bacterial growth consumed oxygen, generally causing the reactor reduction-oxidation values to be in an anaerobic range ( $<0.5 \mathrm{mg} / \mathrm{L}$ for dissolved oxygen), as shown in Table 2. The DOC of effluent water appeared to fluctuate with seasonal effects of the plant growth cycle, metabolic activity in the bioreactor, and acetic acid injection rate. Periodic measurements of acetic acid in effluent water from the lag tanks resulted in below-detectable levels $(<5 \mathrm{mg} / \mathrm{L}$ ). Ammonia-N concentration was $<0.03$ 
$\mathrm{mg} / \mathrm{L}$ under normal operating conditions. Ammonia-N was found in effluent water twice $(0.29$ and $0.21 \mathrm{mg} / \mathrm{L})$ during a period when the facility was not operating as a result of failure of the well pump.

Because birds are attracted to cattails, total and fecal coliform counts were conducted for groundwater remediated in the wetland bioreactor. As shown in Table 3, no fecal coliform was found in the effluent water, but total coliform counts were elevated. Total coliform counts include all aerobic and facultative anaerobic, gram-negative nonspore forming, rod-shaped bacteria that ferment lactose, such as Pseudomonas. An increased coliform population is not unexpected in an open bioreactor located outdoors.

Table 4 shows the results of DGGE fragment or strain information from the dominant band isolated from bioreactor effluent samples. One plant root and only three bacterial matches were identified.

The bacteria species identified from reactor gravel were closely affiliated with species widely distributed in soils, mud layers, and fresh water. Of the 17 dominant bands excised and sequenced, most were gram negative, and respire aerobically or anaerobically with nitrate as the terminal electron acceptor (Pseudomonas, Acinetobacter, Halomonas, and Nitrospira) (Figure 6; Tables 5 and 6). Several identified genera (Rhizobium, Acinetobacter, and Xanthomonas) are capable of fixing atmospheric nitrogen into a combined form (ammonia) utilizable by host plants. Isolates from the Proteobacteria class were identified, a class known for widespread ability to reduce perchlorate.

\section{Discussion}


Several authors have demonstrated that, under proper conditions, perchlorate undergoes a microbially mediated transformation (Malmqvist et al., 1991; Ataway, H. and Smith, M., 1993, Rikken et al., 1996; Urbansky, 1998; Coates et al., 1999; Herman and Frankenberger, 1998; Herman and Frankenberger, 1999; Urbansky and Schock, 1999; Giblin et al., 2000a; and Logan et al., 2001). The groundwater treated during this study (approximately $1900 \mathrm{~kL}$ ) was remediated in a relatively small reactor series (approximately 5.3-kL capacity). Adsorption is not the mechanism of perchlorate removal because the available adsorption sites for perchlorate would eventually be filled. Biological mediated reduction of perchlorate has been used successfully in the remediation of perchlorate in a fixed-bed reactor (Wallace et al., 1996), an autotrophic packed-bed bioreactor (Giblin et al., 2000a) and a wetland bioreactor (Krauter, 2001a). In this work, we field-tested a wetland bioreactor to determine if groundwater containing perchlorate and nitrate could be remediated during long-term field operation under changing seasonal conditions.

When provided with a carbon source, the wetland bioreactor is a sustainable means to remove perchlorate and nitrate from groundwater. Long-term operation with a short hydraulic retention time requires the continuous addition of a carbon source. The rate of perchlorate removal in this study was established with a constant injection of acetic acid that was manually adjusted with the season and maturity of wetland plants. Vegetation provided a long-term, albeit more slowly released, organic carbon supply to denitrifiers; however, the constant supply of acetic acid to the bioreactor helped buffer sudden changes in organic carbon availability from the more labile plants. By using the process 
of acetic acid feed injection, nitrate and perchlorate removal rates were sustainable over the 2-year testing period.

Wetland vegetation supported the microorganisms in several ways. Rootlets provide attachment sites and also leak oxygen, which provides the microorganisms with electron acceptors and increases the amount of organic carbon in the substrate, which, in turn, stimulates microbial activity. The DO and nitrate concentrations in the bioreactor decreased before perchlorate concentration decreased (Krauter, 2001a, b), likely due to microbial populations preferentially using electron acceptors that yield more energy. Oxygen in the bioreactor was consumed first, followed by nitrate, then perchlorate.

Because microbial denitrification depends, in part, on the nature and amount of carbon available to the microorganisms, acetic acid was metered into the reactor. We previously determined that sodium acetate — compared to dried leaf matter, dried algae, and milk replacement starter - was most efficient at accelerating the nitrate and perchlorate removal rates (Krauter 2001b). An HRT of 4 days was required to remove perchlorate $(100 \mu \mathrm{g} / \mathrm{L})$ to below the detection limit $(0.5 \mu \mathrm{g} / \mathrm{L})$, without an added carbon source. With the addition of sodium acetate $(0.26 \mathrm{~g} / \mathrm{L})$, the required HRT decreased to 0.5 days. Bachand and Horne (2000) reported that water temperature and organic carbon availability affect denitrification rates. An additional consideration for managing carbonsource concentrations in the reactor is that the substrate is readily utilized and does not become a food source for microorganisms in the treated groundwater effluent, causing downstream biofouling (Logan, 1998). 
Environmental conditions in the wetland bioreactor fluctuated with seasonal changes, even in California's temperate climate. Seasonal average ambient air temperature ranged between 7 to $11^{\circ} \mathrm{C}$ during the cold season, and between 17 and $26^{\circ} \mathrm{C}$ during the warm season. Depending on the time of day, wetland plants moderated water temperature variations from 1 to $5^{\circ} \mathrm{C}$. The influent water $\mathrm{pH}$ was about 7.5 , and the effluent was about 7.1, well within regulatory discharge limits ( 6.5 to 8.5 units). The $\mathrm{pH}$ was potentially moderated during the growing season by biological carbon dioxide consumption (aquatic photosynthesis). Because nitrate and perchlorate are predominately removed via reductive pathways, the reduction-oxidation potential of about -100 to $-150 \mathrm{mV}$ and dissolved oxygen content of $<1 \mathrm{mg} / \mathrm{L}$ are conducive to anaerobic respiration and denitrification. The reactor effluent was not anaerobic, possibly due to oxygen leaking from plant roots and water mixing during transfers from tank to tank. The lag tanks of the bioreactor generally had a greater DO content, redox value, and no available acetic acid. The lag tanks of the bioreactor were less anaerobic, and ammonia in influent water was generally below the detection level. These designed conditions inhibited or eliminated cogeneration of ammonia. The acetic acid injection rate was varied over time based on reduction-oxidation measurement and the presence, if any, of sulfide in effluent water. Wetland plants were a key part of the bioreactor because they supported the microbial community by providing oxygen and nutrients as well as moderating bioreactor temperatures.

A primary goal of groundwater treatment using a reactor is to sustain optimum reactor performance over long-term operation and under changing seasonal conditions. Stable reactor performance requires that the microbial population be flexible and able to adapt 
the community structure in response to changing conditions, such as flow rate and temperature. Van Ginkel, Plugge, and Stroo (1995) reported that chlorate-reducing inocula sources include wastewater treatment systems and natural ecosystems, suggesting several microbial species capable of this transformation from various sources. In anaerobic conditions, perchlorate undergoes microbial-mediated transformation into chlorate, chlorite, oxygen, and chloride. Several studies have documented a microbially mediated process to reduce perchlorate in surface and groundwater (Urbansky, 1998; Wallace et al., 1998; Krauter, 2001a, b). Coates et al. (1999) found a broad phylogenetic diversity of organisms capable of perchlorate and chlorate reduction.

Analysis of bacterial community structure has historically been done by cultivation-based methods. The PCR-DGGE technique was used in our study because traditional cultivation-based techniques typically include less than $15 \%$ of the cells observed by direct counts (Ward, Weller, and Bateson, 1990; Amann, Ludwig, and Schleifer, 1995).

Our DGGE analysis suggests that microorganisms residing in the wetland bioreactor were related to bacteria capable of degrading nitrate and perchlorate. It is known that $P$. putida and related bacteria readily form biofilm. The bacteria genera identified were closely affiliated with bacteria widely distributed in soils, mud layers, and fresh water. Of the 17 dominant bands sequenced, most were gram negative and capable of aerobic respiration or anaerobic respiration with nitrate as the terminal electron acceptor (Pseudomonas, Acinetobacter, Halomonas, and Nitrospira). Several identified genera (Rhizobium, Acinetobactor, and Xanthomonas) are capable of fixing atmospheric nitrogen into a combined form (ammonia) utilizable by host plants. Isolates from the Proteobacteria class, a class known for widespread ability to reduce perchlorate, were 
also identified. Initial bacterial assessments of wetland-bioreactor sediments confirm the prevalence of facultative anaerobic bacteria capable of reducing perchlorate and nitrate.

The matrix of polysaccharide fibrils produced by the microbial community can form hardy films on the reactor gravel. Despite the bead-beating and vortex process to break up cells, we do not know if the reactor biofilm was sufficiently disturbed to release all microbial DNA. Improvements in initial biofilm breakup and cell lyses procedures are needed. Future studies will include analysis of microbiological community structure over seasonal changes to assess bioreactor adaptation with fluctuating environmental temperatures.

In-ground wetland remediation systems are usually designed for a hydraulic retention time of 7 to 10 days. The wetland bioreactor with acetate feed injection has a hydraulic retention time of about $17 \mathrm{hr}$. The more recalcitrant perchlorate found in the $\mu \mathrm{g} / \mathrm{L}$ range is a more challenging cation to remove from groundwater. In systems where biodegradation is coupled with water transport, the magnitude and rate of biodegradation are influenced by microbial and chemical properties, such as hydraulic residence time, substrate concentration, and electron-acceptor concentration. Such microbial and chemical properties influence the rate of biodegradation within our wetland bioreactor. The results of this study demonstrate the capacity of a simple wetland bioreactor, including indigenous microorganisms, to reduce perchlorate and nitrate in groundwater over several months.

Several species of bacteria capable of degrading nitrate and perchlorate were identified. Because bacterial cells within a biofilm are more resistant to perturbations in the system 
than free-swimming organisms in a liquid matrix, the gravel-based wetland bioreactor can provide a habitat for denitrifying microorganisms to build biofilm.

The results of our study indicate that the microorganisms that inhabit the wetland bioreactor can remove nitrate and perchlorate efficiently and that this capability is natural in the environment and dependent on existing, terminal electron-accepting conditions. The plants and microorganisms in the wetland bioreactor may provide a viable treatment option for nitrate and perchlorate contaminated groundwater.

\section{Acknowledgments}

Work performed under the auspices of the U.S. Department of Energy by UC/Lawrence Livermore National Laboratory under Contract W-7405-Eng-18. 


\section{References}

Amann, R. I., Ludwig W., and Schleifer, K. 1995. Phylogenetic identification and in situ detection of individual microbial cells without cultivation. Microbiol. Rev. 59, $143-169$.

Ataway, H. and Smith, M. 1993. Reduction of perchlorate by an anaerobic enrichment culture. J. Industrial Microbiol. 12, 408-412.

AWWARF (American Water Works Association Research Foundation). 1997. Final Report of the Perchlorate Research Issue Group Workshop, Ontario, CA, Sept.30-Oct. 2, 1997.

Bachand, P. A. M. and Horne A. J. 2000. Denitrification in constructed free-water surface wetlands: II. Effects of vegetation and temperature. Ecological Eng. 14, 17-32.

Coates, J. D., Michaelidou, U., Bruce, R. A., O'Connor, S. M., Crespi, J. N., and Achenbach, L. A. 1999. Ubiquity and diversity of dissimilatory (per)chloratereducing bacteria. Appl. Environ. Microbiol. 65, 5234-5241.

California Department of Health Services. 1997. Determination of Perchlorate by Ion Chromatography. Rev. 0, June 3, 1997.

California Department of Public of Health Services. 2001. California's Experience with Perchlorate in Drinking Water. http://www.dhs.cahwnet.gov/ps/ddwem/chemicals/perchl/perchlindex.htm\#Perchlorate. 
Dionex Corporation. 1998. Application Note 121: Analysis of Low Concentrations of Perchlorate in Drinking Water and Groundwater by Ion Chromatography. Dionex Corp., Sunnyvale, CA, LPN\# 0991-01, 1998.

Ferry, R., Dresen, M., Ferry, L., Isherwood, W., and Ziagos, J. 2001. Site-Wide Remedial Design Work Plan for Interim Remedies at Lawrence Livermore National Laboratory Site 300, Lawrence Livermore National Laboratory, Livermore, CA, UCRL-AR143563.

Giblin, T. L., Herman, D. C., Deschusses M. A., and Frankenberger, Jr., W. T. 2000a. Removal of perchlorate in groundwater with a flow-through bioreactor. J. Environ. Qual. 29, 578-583.

Giblin T. L., Herman, D. C., and Frankenberger, Jr., W. T. 2000b. Removal of perchlorate from groundwater by a hydrogen-utilizing bacteria. J. Environ. Qual. 29, $1057-1062$.

Herman, D. C. and Frankenberger, W. T. 1998. Microbial-mediated reduction of perchlorate in groundwater. J. Environ. Qual. 27, 750-754.

Herman, D. C. and Frankenberger, W. T. 1999. Bacterial reduction of perchlorate and nitrate in water. J. Environ. Qual. 28, 1018-1024.

Hurley, J. A., 2001. Ammonium Perchlorate Treatment Technology Development. Presentation at AFRLIMLQE, Tyndall Air Force Base, FL. 2001. 
Krauter P. 2001a. Using a wetland bioreactor to remediate groundwater contaminated with nitrate $(\mathrm{mg} / \mathrm{L})$ and perchlorate $(\mu \mathrm{g} / \mathrm{L})$. Intl. J. Phytoremediation 3, 415-433.

Krauter P. W. 2001b. Evaluation of Perchlorate Removal in a Wetland Bioreactor. In Proceedings of the $101^{\text {th }}$ Amer. Soc. for Microbiology General Meeting, Orlando, FL, May 20-24 2001.

Logan, B. E. 1998. A review of chlorate- and perchlorate-respiring microorganisms. Bioremediation J. 2, 69-79.

Logan, B. E., Zhang, H, Mulvaney, P, Milner, M. G., Head, I. M., and Unz, R. F., 2001. Kinetics of perchlorate- and chlorate-respiring bacteria. Appl. Environ. Microbiol. 67, 2499-2506.

Malmqvist, A., Welander, T., and Gunnarsson, L. 1991. Anaerobic growth of microorganisms with chlorate as an electron acceptor. Appl. Environ. Microbiol. 57, $2229-2232$.

Nzengung, V. A., Wang, C. H., and Harvey, G. 1999. Plant-mediated transformation of perchlorate into chloride. Environ. Sci. \& Technol. 33, 1470-1478.

Rikken G., Kroon A. G. M., and van Ginkel C. G. 1996. Transformations of (per)chlorate into chloride by a newly isolated bacterium: reduction and dismutation. Appl. Microbiol. Biotechnol. 45, 420-426. 
Smith, P. N., Theodorakis, C. W., Anderson, T.A., and Kendall, R.J. 2001. Preliminary assessment of perchlorate in ecological receptors at the Longhorn Army Ammunition Plant (LHAAP), Karnack, Texas. Ecotoxicology 10, 305-313.

Urbansky, E.T. 1998. Perchlorate chemistry: implications for analysis and remediation. Bioremediation J. 2, 81-95.

Urbansky, E.T., and M. R. Schock. 1999. Issues in managing the risks associated with perchlorate in drinking water. J. Environ. Manag. 56, 79-95.

U.S. Environmental Protection Agency (U.S. EPA), Office of Groundwater and Drinking Water. 2001. Perchlorate. http://www.epa.gov/ogwdw000/ccl/perchlor/perchlo.html.

van Ginkel, C. G., Plugge, C. M., and Stroo, C. A.. 1995. Reduction of chlorate with various energy substrates and inocula under anaerobic conditions. Chemosphere 31, $4057-4066$

Wallace, W., Ward, T., Breen, A., and Attaway, H. 1996. Identification of an anaerobic bacterium which reduces perchlorate and chlorate as Wolinella Succinogenes. J. Ind. Microbiol. 16, 68-72.

Wallace, W., Beshear, S., Williams, D., Hospadar, S., and Owens, M. 1998. Perchlorate reduction by a mixed culture in an up-flow anaerobic fixed bed reactor. $J$. Ind. Microbiol. Biotechnol. 20, 126-131.

Ward, D. M., Weller, R., and Bateson, M. M. 1990. 16sRNA sequences reveal numerous uncultured microorganisms in a natural community. Nature 344, 63-65. 
Weisburg, W .G., Barns S. M., Pelletier D. A., and Lane D. J. 1991. 16s ribosomal DNA amplification for phylogenetic study. J. Bacteriol. 173, 697-703. 
Table 1. Groundwater analysis for well W-854-03.

\begin{tabular}{|c|c|}
\hline Analyte & $\begin{array}{c}\text { Result } \\
\text { (mg/L unless otherwise noted) }\end{array}$ \\
\hline Aluminum & $<0.2$ \\
\hline Ammonia (as N) & $<0.1$ \\
\hline Total alkalinity (as $\left.\mathrm{CaCo}_{3}\right)$ & 240 \\
\hline Chloride & 230.0 \\
\hline Dissolved oxygen $^{\mathrm{a}}$ & 8.0 \\
\hline Dissolved organic carbon & 1.4 \\
\hline$E_{\mathrm{h}}\left(\mathrm{mV}\right.$ at $\left.21.8^{\circ} \mathrm{C}\right)$ & 118 \\
\hline$E_{\mathrm{h}}\left(\mathrm{mV}\right.$ at $\left.18.4^{\circ} \mathrm{C}\right)$ & 167 \\
\hline Hardness $\left(\mathrm{as} \mathrm{CaCo}_{3}\right)$ & 220.0 \\
\hline Iron & $<0.1$ \\
\hline Magnesium & 26.0 \\
\hline Manganese & $<0.03$ \\
\hline Nitrate (as $\mathrm{NO}_{3}{ }^{-}$) & 47.8 \\
\hline Nitrite (as $\mathrm{NO}_{2}{ }^{-}$) & $<0.5$ \\
\hline Total Kjeldahl nitrogen & 0.2 \\
\hline Perchlorate $(\mu \mathrm{g} / \mathrm{L})$ & $6-14$ \\
\hline $\mathrm{pH}$ & 7.6 \\
\hline o-phosphate & $0.10-0.15$ \\
\hline Potassium & 7.8 \\
\hline Specific conductivity $(\mu \mathrm{mhos} / \mathrm{cm})$ & 820 \\
\hline Sulfate & $20-58$ \\
\hline Sulfide & $<0.1$ \\
\hline Sodium & 180 \\
\hline Trichloroethene $(\mu \mathrm{g} / \mathrm{L})$ & 120 \\
\hline Total dissolved solids & 750 \\
\hline Total VOC $(\mu \mathrm{g} / \mathrm{L})$ & $98-110$ \\
\hline Zinc & $<0.5$ \\
\hline
\end{tabular}

${ }^{a}$ Analyses for dissolved oxygen, $E_{\mathrm{h}}, \mathrm{pH}, o$-phosphate, and sulfide were conducted in the field. 
Table 2. Monthly air and water temperatures, dissolved organic carbon, dissolved oxygen, $\mathrm{pH}$, and reduction-oxidation potential from the bioreactor during the first two years of operation.

\begin{tabular}{|c|c|c|c|c|c|c|c|}
\hline $\begin{array}{l}\text { Reactor } \\
\text { age } \\
\text { (month) }\end{array}$ & $\begin{array}{c}\text { Average } \\
\text { ambient air } \\
\text { temp. } \\
\left({ }^{\circ} \mathrm{C}\right)\end{array}$ & $\begin{array}{l}\text { Average } \\
\text { water } \\
\text { temp. } \\
\left({ }^{\circ} \mathrm{C}\right)\end{array}$ & $\begin{array}{l}\text { Reduction- } \\
\text { oxidation } \\
\text { potential } \\
(\mathrm{mV})\end{array}$ & $\begin{array}{l}\text { Dissolved } \\
\text { oxygen } \\
\text { (mg/L) }\end{array}$ & $\begin{array}{c}\text { Dissolved } \\
\text { organic } \\
\text { carbon } \\
(\mathrm{mg} / \mathrm{L})\end{array}$ & $\begin{array}{c}\text { Influent } \\
\text { pH }\end{array}$ & $\begin{array}{c}\text { Effluent } \\
\text { pH }\end{array}$ \\
\hline 0 & 10.6 & 20.4 & 18 & 8.0 & 1.5 & 7.6 & 7.3 \\
\hline 1 & 6.6 & 11.0 & -79 & 1.5 & 8.7 & 7.5 & 6.9 \\
\hline 2 & 9.2 & 10.5 & 3.5 & 0.8 & 1.0 & 7.5 & 7.2 \\
\hline 3 & 7.6 & 7.5 & 11.5 & 5.2 & 0.0 & 7.6 & 7.1 \\
\hline 4 & 10.5 & 12.0 & -45 & 3.0 & 1.2 & 7.5 & 7.1 \\
\hline 5 & 23.1 & 18.0 & -111 & 0.6 & Not sampled & 7.5 & 7.0 \\
\hline 6 & 26.6 & 24.2 & -130 & 0.2 & 3.4 & 7.5 & 6.9 \\
\hline 7 & 18.0 & 20.9 & -127 & 1.5 & 1.7 & 7.5 & 6.9 \\
\hline 8 & 26.0 & 25.4 & -48 & 0.3 & 2.0 & 7.6 & 7.2 \\
\hline 9 & 18.7 & 22.4 & -158 & 2.2 & 1.5 & 7.5 & 7.1 \\
\hline 10 & 24.8 & 23.0 & -164 & 0.1 & Not sampled & 7.5 & 7.3 \\
\hline 11 & 18.3 & 22.1 & -115 & 0.3 & 1.5 & 7.5 & 7.1 \\
\hline 12 & 13.2 & 16.0 & -134 & 0.5 & 2.4 & 7.6 & 7.3 \\
\hline 13 & 8.4 & 10.0 & -213 & 0.6 & 5.5 & 7.6 & 7.2 \\
\hline 14 & 7.4 & 8.8 & -167 & 0.8 & 74 & 7.4 & 7.2 \\
\hline 15 & 11.0 & 10.0 & -110 & 0.3 & 1.6 & 7.5 & 7.2 \\
\hline 16 & 11.3 & 14.2 & -150 & 0.2 & 50 & 7.5 & 7.0 \\
\hline 17 & 13.6 & 15.5 & -120 & 0.4 & 1.4 & 7.5 & 7.1 \\
\hline 18 & 17.5 & 16.0 & -134 & 0.6 & 2.2 & 7.5 & 7.0 \\
\hline 19 & 22.0 & 18.3 & -177 & 0.8 & 1.0 & 7.4 & 7.2 \\
\hline 20 & 25.9 & 23.0 & -162 & 0.4 & 1.0 & 7.4 & 7.2 \\
\hline 21 & 24.8 & 22.2 & -150 & 1.1 & 2.7 & 7.5 & 7.3 \\
\hline 22 & 23.8 & 21.7 & -185 & 0.5 & Not sampled & 7.5 & 7.1 \\
\hline 23 & 17.6 & 19.9 & -144 & 1.0 & $<0.8$ & 7.5 & 7.0 \\
\hline 24 & 13.5 & 17.6 & -101 & 0.8 & 1.2 & 7.5 & 7.2 \\
\hline
\end{tabular}


Table 3. Total coliform counts [most probable number (MPN)] for bioreactor influent and effluent water.

\begin{tabular}{|l|c|c|}
\hline \multicolumn{1}{|c|}{ Sample } & $\begin{array}{c}\text { Total coliform count } \\
\text { (MPN/100 } \mathbf{~} L)\end{array}$ & $\begin{array}{c}\text { Fecal coliform count } \\
\text { (MPN/100 } \mathbf{~ L L})\end{array}$ \\
\hline Influent & 1600 & $<2$ \\
\hline Bioreactor effluent & $\geq 2400$ & $<2$ \\
\hline Final effluent & 920 & $<2$ \\
\hline
\end{tabular}


Table 4. DGGE fragment or strain information from dominant bands isolated from water samples exiting the wetland bioreactor.

\begin{tabular}{|c|l|c|c|}
\hline $\begin{array}{c}\text { Band } \\
\text { number }\end{array}$ & \multicolumn{1}{|c|}{ Species } & $\begin{array}{c}\text { Similarity } \\
(\%)\end{array}$ & $\begin{array}{c}\text { Accession } \\
\text { number }\end{array}$ \\
\hline 14 & Oryza sativa (plant root rice) & 100 & $\mathrm{AP03052}$ \\
\hline 15 & $\begin{array}{l}\text { epsilon proteobacterium } \\
\text { sulfuricurvum sp. }\end{array}$ & 85 & $\mathrm{AB} 030609$ \\
\hline 16 & Desulfovibrio giganteus & 95 & $\mathrm{AF} 418170$ \\
\hline 17 & Sulfuricurvum kijiensl & 83 & $\mathrm{AB} 080645$ \\
\hline
\end{tabular}


Table 5. DGGE fragment or strain information from dominant bands isolated from reactor gravel at several depths in the lead tank.

\begin{tabular}{|c|c|l|c|c|}
\hline $\begin{array}{c}\text { Band } \\
\text { number }\end{array}$ & $\begin{array}{c}\text { Sample depth } \\
\text { (in.) }\end{array}$ & \multicolumn{1}{|c|}{ Species } & $\begin{array}{c}\text { Similarity } \\
(\%)\end{array}$ & $\begin{array}{c}\text { Accession } \\
\text { number }\end{array}$ \\
\hline 1 & 9 & Nitrosprira sp & 82 & AY114337 \\
\hline 2 & 9 & Ps. Nitroreducens & 82 & D84022 \\
\hline 3 & 18 & Ps. Migulae & 94 & AF501370 \\
\hline 4 & 18 & Rhizobium sp. & 89 & AF063995 \\
\hline 5 & 18 & Ps. Stutzeri & 82 & AJ410872 \\
& 18 & Ps. Nitroreducens & 82 & D84022 \\
\hline 6 & 18 & Halomonadaceaebacterium & 95 & AF513453 \\
\hline 7 & 25 & Xanthomonaceae bacterium & 82 & X95918 \\
\hline 8 & 25 & Acinetobacter sp. & 85 & AF356748 \\
\hline
\end{tabular}


Table 6. DGGE fragment or strain information from dominant bands isolated from reactor gravel at several depths in the lag tank.

\begin{tabular}{|c|c|l|c|c|}
\hline $\begin{array}{c}\text { Band } \\
\text { number }\end{array}$ & $\begin{array}{c}\text { Sample depth } \\
\text { (in.) }\end{array}$ & \multicolumn{1}{|c|}{ Species } & $\begin{array}{c}\text { Similarity } \\
\text { (\%) }\end{array}$ & $\begin{array}{c}\text { Accession } \\
\text { number }\end{array}$ \\
\hline 9 & 9 & Ralstonia sp. & - & - \\
\hline 10 & 9 & Not determined & - & - \\
\hline 11 & 9 & Not determined & - & - \\
& 18 & Not determined & - & - \\
\hline 12 & 26 & Not determined & - & - \\
\hline 13 & 26 & Ps. Nitroreducens & 82 & D84022 \\
\hline
\end{tabular}




\section{Figure Legends}

Figure 1. Location map of Site 300.

Figure 2. Building 854 complex showing (a) TCE, (b), perchlorate, and (c) nitrate concentrations in groundwater.

Figure 3. Schematic diagram of the Building 854 groundwater extraction and treatment facility.

Figure 4. Perchlorate concentration of influent groundwater and water processed through the treatment facility.

Figure 5. Nitrate concentration of influent groundwater and water processed through the treatment facility from November 2000 through March 2002.

Figure 6. PCR-DGGE fingerprints from the wetland bioreactor. Numbered gel lanes contain PCR-amplified, 16S rRNA gene fragments from gravel pulled from several sample depths in the reactor. Lanes flanking the numbered lanes contain a reference fingerprint used to confirm consistent gradient of denaturants across a gel. 


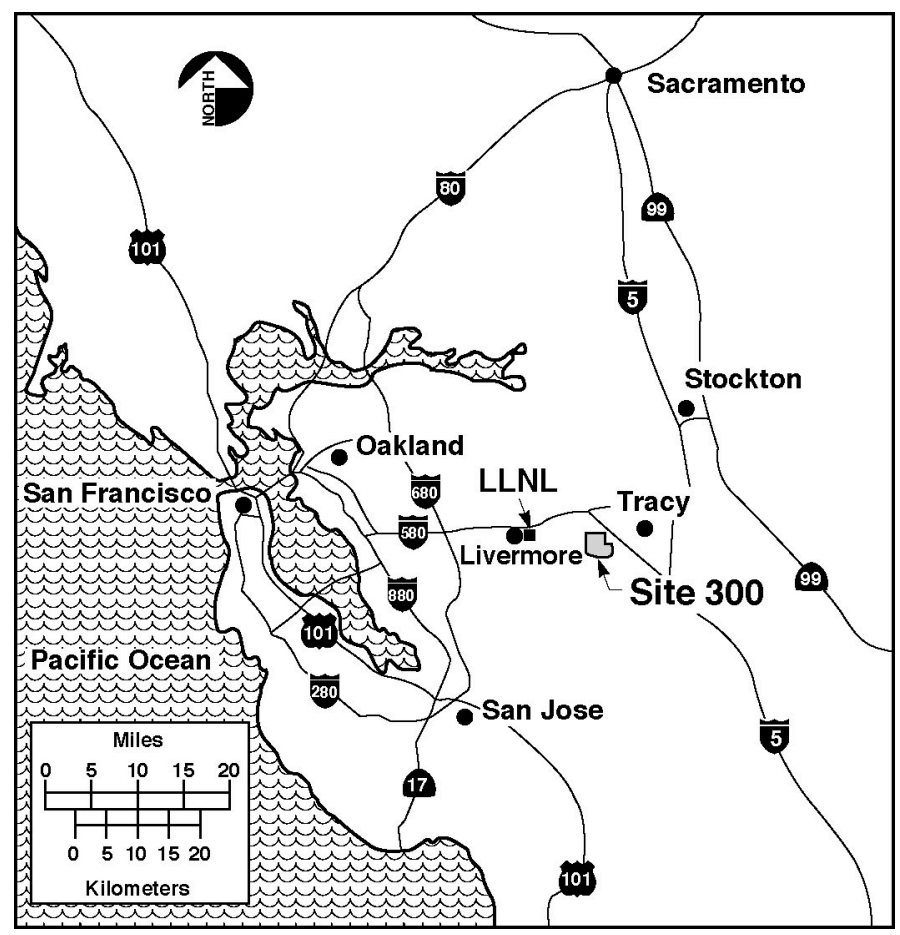

Figure 1. 
(a) TCE

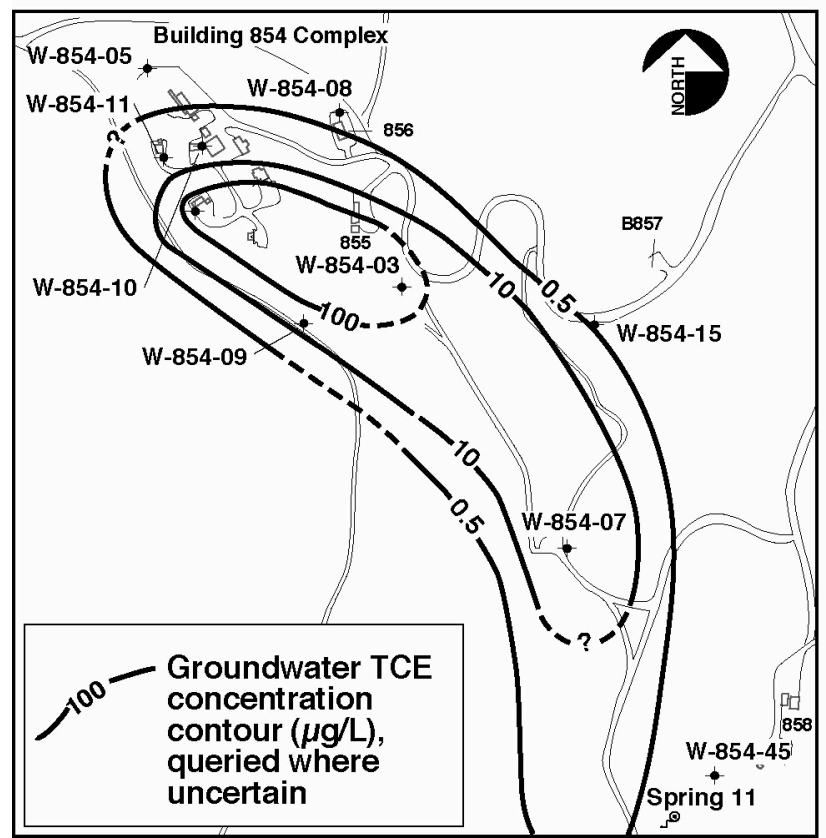

\begin{tabular}{|l} 
Legend \\
- Monitor well \\
Spring \\
Scale: Feet \\
Sroundwater treatment unit \\
Scaller 800
\end{tabular}

Figure 2(a). 
(b) Perchlorate

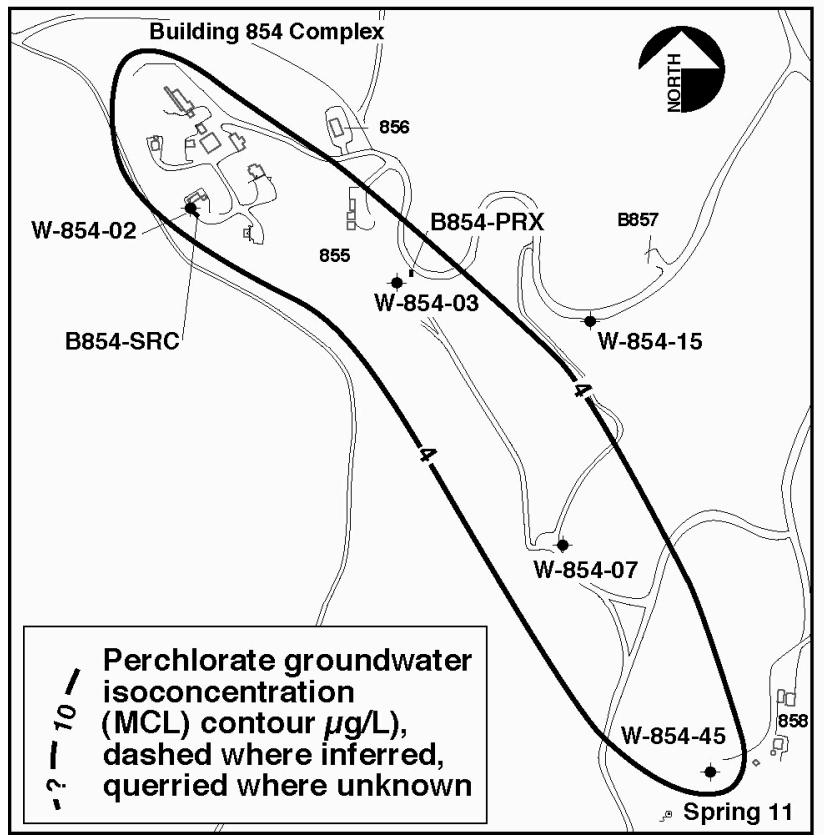

\begin{tabular}{|l|l|} 
Legend \\
Sonitor well \\
Spring \\
Scaled water-supply well \\
Scale: Feet \\
$0 \quad 400 \quad 800$
\end{tabular}

Figure 2(b). 


\section{(c) Nitrate}

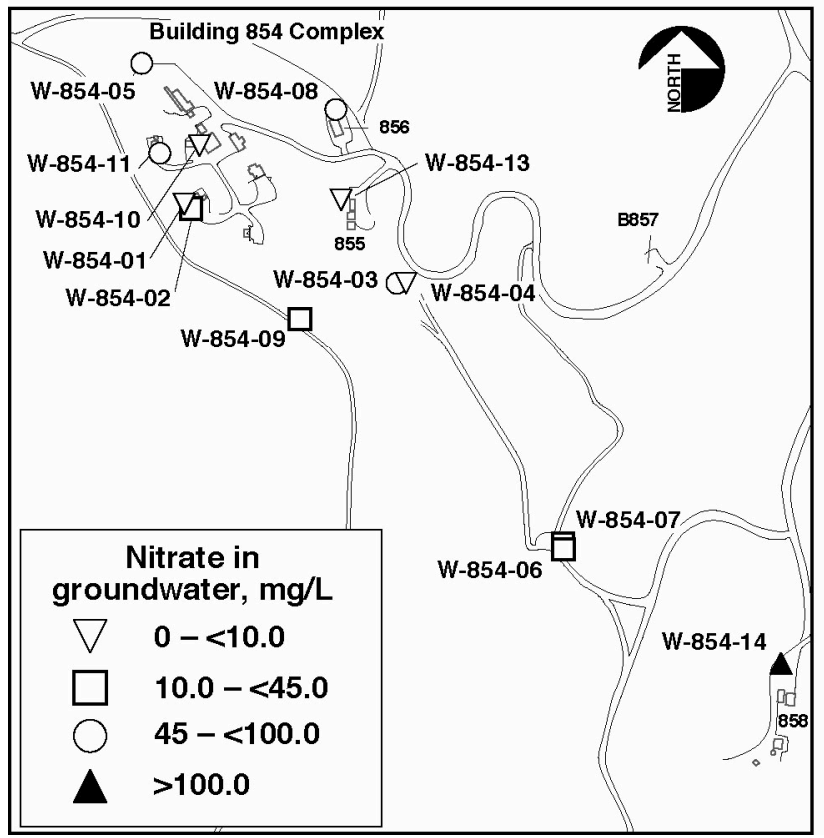

\begin{tabular}{|l} 
Legend \\
- Monitor well \\
Spring \\
- Sealed water-supply well \\
Scale: Feet \\
- Groundwater treatment unit
\end{tabular}

Figure 2(c). 


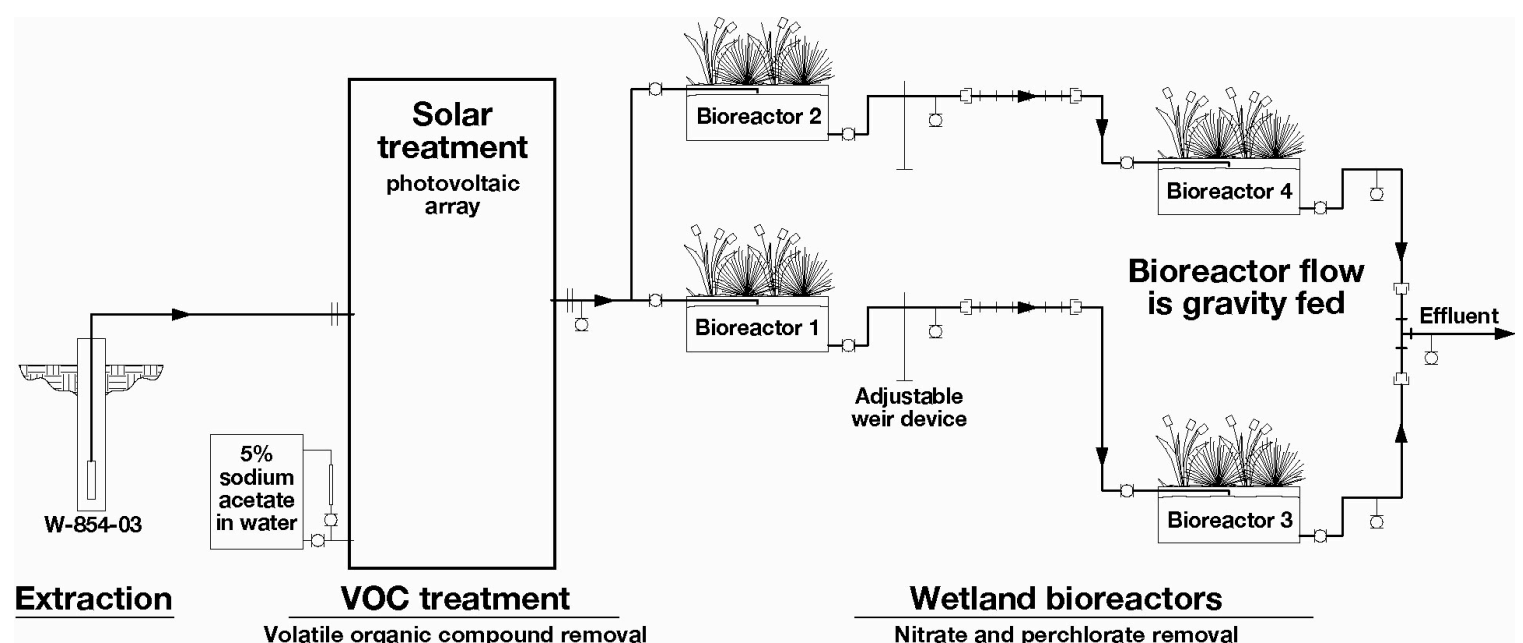

Figure 3. 


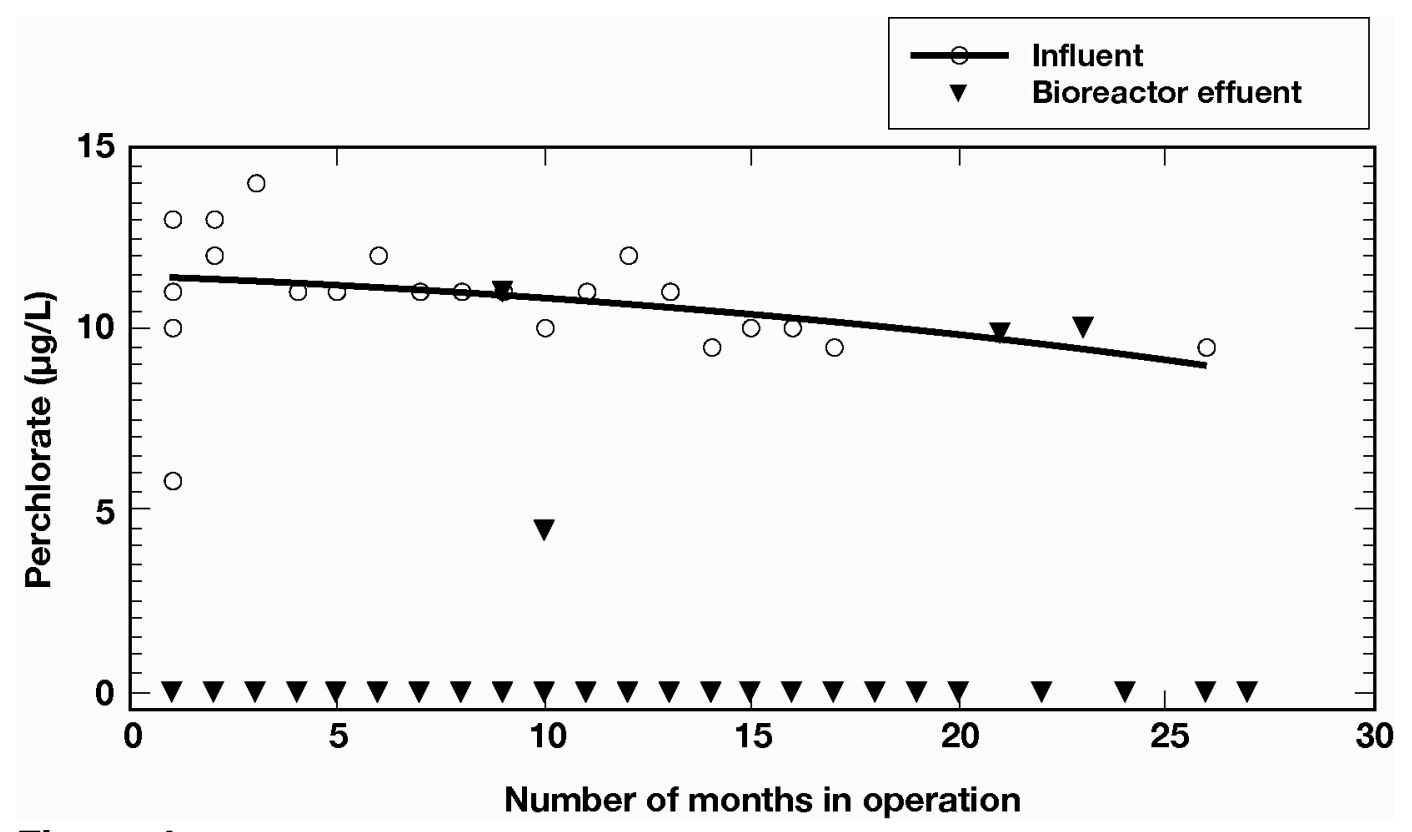

Figure 4. 


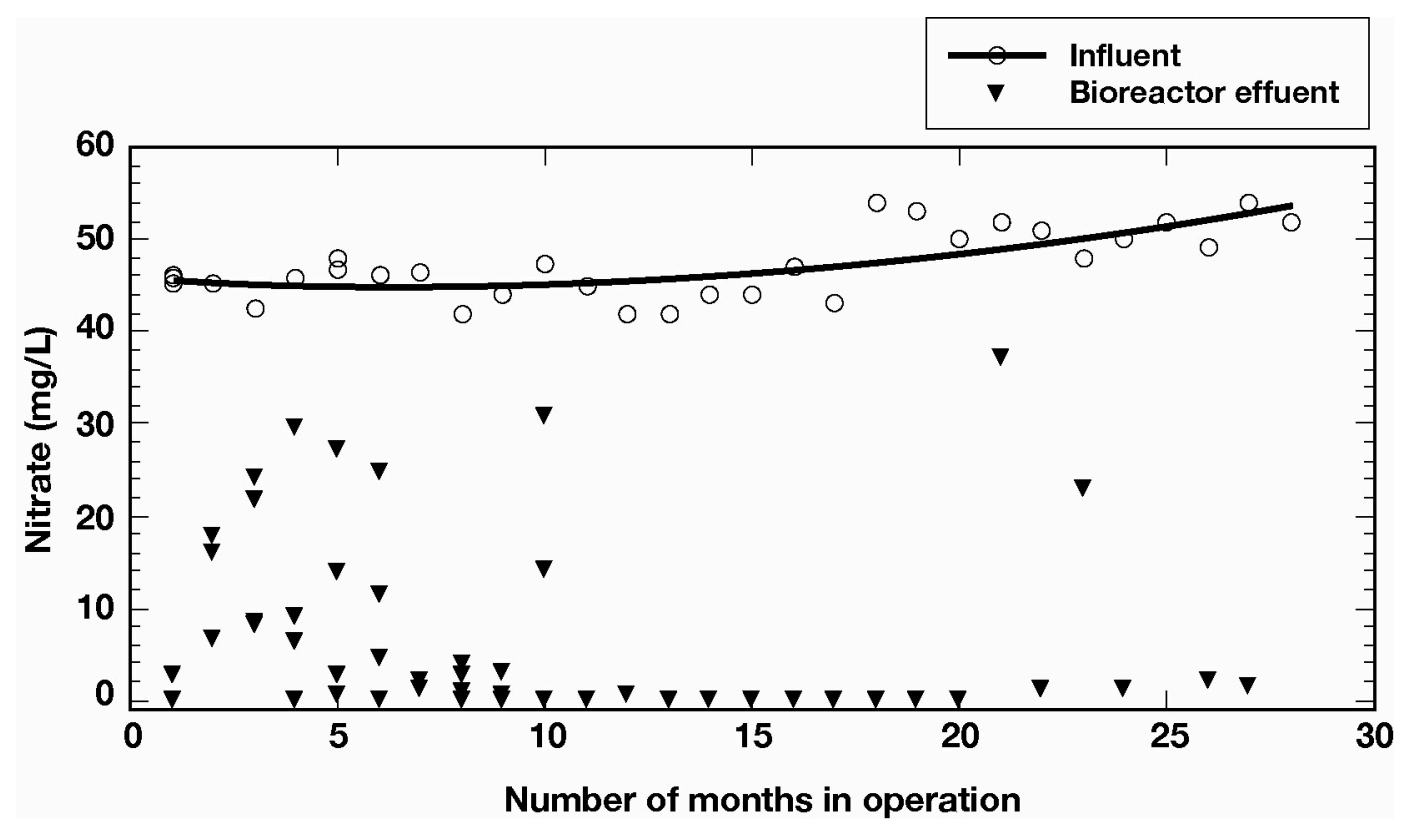

Figure 5. 


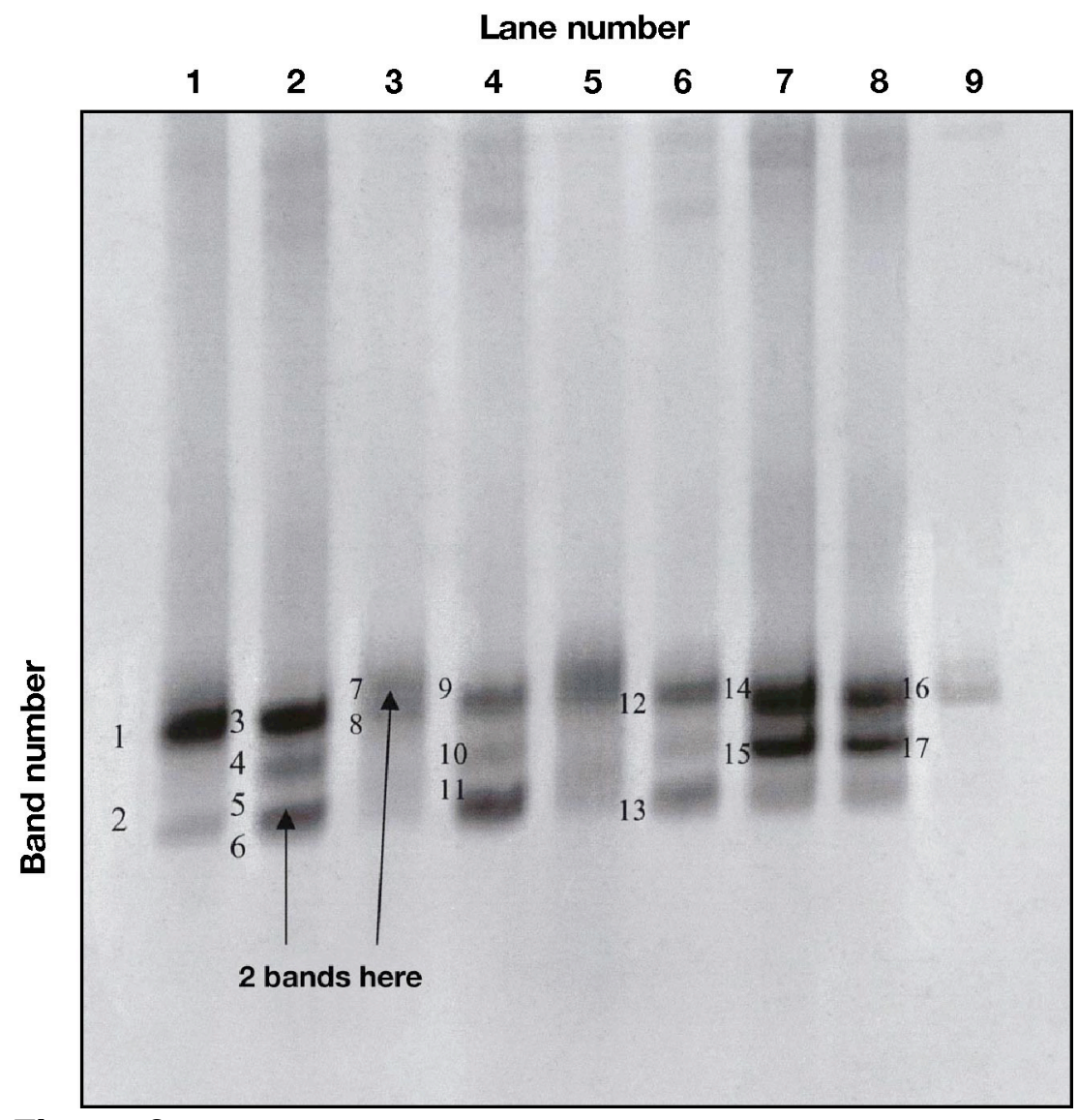

Figure 6. 